\title{
Editorial: Unusual Subduction Processes
}

\author{
Vlad Constantin Manea ${ }^{1,2 \star}$, Marina Manea ${ }^{1,3}$, Min Chen $^{4}$, Jeroen van Hunen ${ }^{5}$ and \\ Matthias Konrad-Schmolke ${ }^{6}$ \\ ${ }^{1}$ Computational Geodynamics Laboratory, Centro de Geociencias, Universidad Nacional Autónoma de México, Mexico City, \\ Mexico, ${ }^{2}$ Research Institute of the University of Bucharest-iCUB, University of Bucharest, Bucharest, Romania, ${ }^{3}$ Astronomical \\ Institute of the Romanian Academy, Bucharest, Romania, ${ }^{4}$ Michigan State University, East Lansing, MI, United States, ${ }^{5}$ Durham \\ University, Durham, United Kingdom, ${ }^{6}$ University of Gothenburg, Gothenburg, Sweden
}

Keywords: subduction zones, intermediate-depth seismicity, geochemistry, flat slab subduction, numeric modeling

\section{Editorial on the Research Topic}

\section{Unusual Subduction Processes}

Subduction zones display arguably the most complex geodynamic setting on Earth, which driven the Earth's interior dynamics and shaped the Earth's surface since the onset of plate tectonics. Processes within subduction zones comprise large earthquakes and volcanic eruptions, generation of continental crust, ore formation as well as long-term element exchange between atmosphere, hydrosphere and the Earth's interior, all of which are of fundamental societal, economic and scientific interest. Despite significant progress in our understanding of the bulk of subduction zones, many regions with unusual tectonic characteristics continue to be a challenge, as they do not always straightforwardly fit into the plate tectonic paradigm. Key questions remain regarding the complex dynamics associated with subduction zones. Addressing these problems is essential if we want to understand the role of subduction in the Earth's distant past or future, or if we want to reduce the significant natural hazards associated with plate subduction. It has become increasingly clear that significant progress can only be made through multidisciplinary research that combines new hypotheses, observations, and modeling. The set of 10 papers in this special Research Topic on the "Unusual Subduction Processes" aims to provide a multidisciplinary framework for future research efforts.

Flat slab subduction is one of the most unusual subduction geometries that challenge our view on how subduction is the key driver behind plate tectonics. Using numerical modeling, Schellart shows that only wide subduction zones $(>6,000 \mathrm{~km})$ have a predisposition to a shallow dip angle in the central part, where ultimately slab flattening can occur after a prolonged period of subduction (>80-110 Myr).

Unusual slab behavior at the interface between the upper and lower mantle illustrates that this mantle transition zone remains enigmatic. Employing numerical modeling, Grima et al. show that a slab orphaning regime, where the slab tip detaches at $660 \mathrm{~km}$ depth and is abandoned by its parent slab, provides a dynamic link between the stagnation and penetration regimes. Similarly, Tsucida and Kameyama demonstrate numerically that the descent of stagnant slabs at $660 \mathrm{~km}$ depth is controlled by the specific history of trench retreat. Acceleration of trench retreat favors the formation of horizontallylying slabs at the base of the transition zone, whereas deceleration enhances the collapse of stagnant slabs into the lower mantle. Slab detachment dynamics is investigated in detail by Thielmann and Schmalholz who demonstrate that the slab break-off is mainly controlled by grain damage, but in the later stages thermal weakening becomes dominating. Connecting the two processes induces a thermomechanical chain effect resulting in more efficient slab detachment.

The interaction between mid-ocean ridges and subduction zones represents another complex process that produces major changes in arc-related magmatic activity and creating a unique 
geological signature on overriding plates. Iannelli et al. combine new isotopic geochemical data with seismic tomography to track such tectonic changes that affected the Andean margin from Latest Cretaceous to early Miocene times. The magmatic arc isotopic composition records reveal time-space variations of a partially enriched mantle source which reflect the existence of a slab window that migrated southward along the Southern Central Andes until Eocene times. The common view about how subduction zones work is challenged by Leeman who used the atypical Cascades volcanic arc as a test site that is broader than usual, with significant basaltic volcanism located in frontal and back arc regions. Using thermobarometry of the most primitive basalts Leeman underpins the unusual relationships between depth and composition that yield conflicting views regarding melt generation.

Another important process observed in subduction zones along continental margins characterized by slab edges is mantle tearing, or delamination, which is accommodated by subduction-transform edge propagator faults. Negredo et al. investigate numerically the necessary conditions to trigger such continental mantle delamination associated with a seismically imaged subduction-transform edge propagator fault under the central Betic orogen at the northern edge of the Gibraltar arc subduction. They found a combination of specific conditions favoring slow or rapid continental delamination, as a strong density contrast between the orogenic and a thinned back-arc lithosphere, as well as a thick and mechanically weak lower crust along the continental margin. Understanding such mechanics of continental lithosphere in the context of mantle dripping is also of paramount importance to understand tectonic processes throughout Earth's history. Gunawardana et al. investigate numerically the lithospheric yield stress for conditions appropriate to the early-to-mid Archean Earth. Their results indicate that lithospheric yield stress values of less than $100 \mathrm{MPa}$ can generate crustal trondhjemite-granodiorite volumes that indicate the dominance of lithospheric dripping in Archean.

Seismicity associated with subduction zones can also reveal key processes that occur at different depth ranges. Wagner et al. show that subduction zones with thick oceanic crust have little seismicity at intermediate depths, whereas adjacent regions with normal oceanic crust are characterized by intense seismicity at similar depths. Based on this particular distribution of intermediate depth seismicity, Wagner et al. advance a new provocative hypothesis. For subduction regions with normal thickness oceanic crust the intraslab seismicity is caused by mantle dehydration reactions, whereas areas characterized by unusual thick oceanic crust seismicity is almost absent due to the inability to seawater to penetrate and hydrate the lithospheric mantle before arrival at the trench.

Subduction zones may not only be affected by unusual thicknesses of the incoming oceanic crust, but also by atypical forearc dynamics. Using continuous GPS records gathered over a time span of more than a decade in the Guerrero region in Mexico, Kazachkina et al. reveal an active $\sim 650 \mathrm{~km}$ long shear zone parallel to the Middle America trench. This left-lateral shear zone delimits a wide forearc sliver that moves over the subducting Cocos plate at a rate of $3-6 \mathrm{~mm} / \mathrm{yr}$ with respect to the North America plate. The long-term effects of such sliver on the subduction dynamics for the unusually shallow Mexican flat slab are yet to be quantified.

We hope that the reader will find this Research Topic collection of papers a useful reference for future research on subduction zones and related processes.

\section{AUTHOR CONTRIBUTIONS}

VM, MM, MC, JvH, and MK edited the Research Topic of Unusual Subduction Processes. VM wrote the manuscript, and $\mathrm{MM}, \mathrm{MC}, \mathrm{JH}$, and $\mathrm{MK}$ provided comments and suggestions, and revised the manuscript.

\section{FUNDING}

This work was partially supported by a grant of the Romanian Ministry of National Education and Scientific Research, RDI Program for Space Technology and Advanced Research (STAR), Romania, as well as by the Research Institute of the University of Bucharest-ICUB, University of Bucharest.

Conflict of Interest: The authors declare that the research was conducted in the absence of any commercial or financial relationships that could be construed as a potential conflict of interest.

Copyright $\odot 2020$ Manea, Manea, Chen, van Hunen and Schmolke. This is an openaccess article distributed under the terms of the Creative Commons Attribution License (CC BY). The use, distribution or reproduction in other forums is permitted, provided the original author(s) and the copyright owner(s) are credited and that the original publication in this journal is cited, in accordance with accepted academic practice. No use, distribution or reproduction is permitted which does not comply with these terms. 